\title{
Lidil
}

Revue de linguistique et de didactique des langues

Sémantique des noms et adjectifs d'émotion

\section{Sočuvstvie and Sostradanie}

A Semantic Study of two Russian Emotions

The Natural Semantic Metalanguage Approach

Anna Gladkova

\section{(2) OpenEdition}

Édition électronique

URL : http://journals.openedition.org/lidil/93

DOI : $10.4000 /$ lidil.93

ISSN : 1960-6052

Éditeur

UGA Éditions/Université Grenoble Alpes

\section{Édition imprimée}

Date de publication : 1 décembre 2005

ISBN : 2-914176-13-9

ISSN : 1146-6480

\section{Référence électronique}

Anna Gladkova, «Sočuvstvie and Sostradanie », Lidil [En ligne], 32 | 2005, mis en ligne le 16 juillet 2007, consulté le 01 mai 2019. URL : http://journals.openedition.org/lidil/93 ; DOI : 10.4000/lidil.93

Ce document a été généré automatiquement le 1 mai 2019.

(C) Lidil 


\title{
Sočuvstvie and Sostradanie
}

\author{
A Semantic Study of two Russian Emotions \\ The Natural Semantic Metalanguage Approach
}

\section{Anna Gladkova}

1 If one wants to appreciate a certain culture and master its language it is essential to understand this culture's prominent attitudes conceptualised in the lexicon of the language. The Russian culture has often been described as possessing communal character (Berdyaev, 2000; Boym, 1994) and as being strong in emotional expression (Wierzbicka, 1992; 1999; Pavlenko, 2002; Gerhart, 2001). These two attitudes are embedded in the words sočuvstvie (usually translated into English as 'sympathy') and sostradanie (usually translated into English as 'compassion')'. These words describe emotions which are caused by the realization of a negative emotional state of another person. Understanding of the meanings of these words will give us a key to understanding of the ways of thinking and behaving specific to Russian culture.

2 The semantic description of these two words poses several challenges. Firstly, they do not have exact equivalents in other languages, which aggravates the task of explaining their meanings to outsiders. Even though the ability to 'feel for another person'is often considered a universal quality distinguishing humans from animals, a simple linguistic analysis can show that this « ability » is conceptualised differently in different languages. For example, the English sympathy is commonly regarded as a translational counterpart of the Russian sočuvstvie. However, these words have different meanings, which can be shown by their different combinatorial properties. Russian sočuvstvie can be qualified as serdečnoe 'cordial', družeskoe 'friendly', gorjačee 'hot', neposredstvennoe 'ingenuous', živoe 'lively', nevol'noe 'involuntary', neskryvaemoe 'unconcealed'or dejstvennoe 'efficient' ${ }^{2}$. All these collocations are a sign of an outgoing character of emotion, which is inherent to the Russian sočuvstvie. This characteristic is not an attribute of the English sympathy and no such or similar collocations are found in the corpus of the English language (COBUILD). In English qualifiers of sympathy express the degree of intensity of the feeling (deep, deepest, great, greatest, much, a lot of). Thus, the differences in combinatorial properties of sočuvstvie e and sympathy indicate differences in their meanings: sočuvstvie is an emotion which is expected to be manifested and expressed in various ways; sympathy is a feeling 
which can be intense, but not necessarily shown to other people. This consideration correlates with the general tendency of free emotional expression characteristic of the Russian culture and not specific to norms in Anglo-Saxon cultures (Wierzbicka, 1992, 1997; Pavlenko, 2002). Thus, sympathy and compassion are only approximate translations of the Russian words sočuvstvie and sostradanie.

The second challenge of the semantic analysis of the words sočuvstvie and sostradanie lies in the closeness of their meanings. This similarity in meaning is predetermined by their specific morphological and syntactic characteristics: both words are formed with the prefix so- (co-) - a marker of communal activity, and are used in almost identical syntactic frames. Thus, a semantic analysis should be able to comprehensively capture similarities and differences between these words.

When a linguist faces a task like this, the choice of a tool for semantic analysis becomes the most significant factor in the successful outcome of the task. An approach where emotions are described via other emotion terms cannot be reliable because emotions cannot be described in terms of degree only. To avoid the trap of circularity and language-bias we need to use words that are simple in meaning and that can be easily translated into other languages. The linguistic theory known as the Natural Semantic Metalanguage (NSM), developed by Wierzbicka and Goggard, can be regarded as an adequate tool for our task. On the basis of profound empirical research, it suggests an inventory of about 60 or so universal semantic concepts which have universal and simple character (Goddard and Wierzbicka eds., 1994, 2002). This postulate means that these words cannot be defined further and they have exact semantic equivalents in all languages, which makes them reliable units in semantic analysis. According to the NSM theory, these semantic components used in certain combinations become constituents of comprehensive definitions which can be easily transferred into any language. In the description of emotions the following semantic primitives can be used: PERSON, FEEL, SOMETHING, GOOD, BAD, THINK, BECAUSE, HAPPEN. Thus, the NSM method will make it possible to formulate semantic explications of the words sočuvstvie and sostradanie. These explications will comprise simple words and will be written in the form of short texts decoding meanings of these words. The precision of an explication can be tested by its substitution into the contexts of occurrence of the word.

5 Another important methodological requirement concerns the format of presentation of semantic explications of emotions. It can be assumed that « emotions are feeling-states that have a cognitive component » (Peyroux, 2004: 309) and, thus, should be described in terms of a prototypical cognitive scenario in the mind of the speaker (Wierzbicka, 1999; Goddard, 1998). Sočuvstvie and sostradanie are emotions which are caused by a certain way of thinking about another person and, thus, belong to the array of so called emotions of social character. In explications this will be formulated as the following semantic components: « person $\mathrm{X}$ thinks about person $\mathrm{Y}$ like this... when $\mathrm{X}$ thinks like this about $\mathrm{Y}$, X feels something... » (cf. Wierzbicka, 1999; Goddard, 1998).

This paper will offer a detailed semantic analysis of the words sočuvstvie and sostradanie using the Natural Semantic Metalanguage as a tool of semantic description. This will make it possible to show subtle semantic differences between these terms and also identify the unique configuration of components encoded in each of them. Factors of syntactic frames of use, combinatorial properties and morphological structure will be considered in the semantic analysis. In section 2 the syntactic frames of use and semantic components of the word sočuvstvie will be discussed in detail. Section 3 will be devoted to 
the description of frames of use and semantic components of sostradanie which will then be compared with those of sočuvstvie. Each section will close with a semantic explication written in the Natural Semantic Metalanguage.

The meaning of sočuvstvieThe syntactic frames of use of the word sočuvstvie

Combinatorial and syntactic properties of a word are suggestive of its meaning. Sočuvstvie collocates with verbs of the following meaning: (a) the causation of the feeling (vyzyvat' 'arouse', ročdat' 'give rise to') ; (b) the experiencing of the feeling (ispytyvat' 'experience/ feel', voznikat' 'arise', proniknut' sja 'be filled with') and (c) the expression of the feeling ( projavljat' 'reveal', pokazyvat' 'show', vyračat' 'express', vykazyvat' 'manifest/display', izobražat' 'express/ represent').

Sočuvstvie is also used in genitive prepositional constructions of cause. In constructions with the preposition ot 'from' sočuvstvie combines with verbs expressing emotional manifestation associated with this feeling: zastonat' ot sočuvstvija 'to moan from sočuvstvie', rastajat'ot sočuvstvija 'to melt from sočuvstvie', usmexnut' sja ot sočuvstvija 'to grin from sočuvstvie'. Another group of verbs expressing helping or caring action caused by this feeling combines with sočuvstvie via the preposition iz 'out of': dostavit'kogo-to $v$ bol'nicu iz sočuvstvija 'to bring someone to the hospital out of sočuvstvie', deržat'kogo-to na rabote iz sočuvstvija 'to keep a working position for someone out of sočuvstvie', zajti k komu-to $v$ gosti iz sočuvstvija 'to pay someone a visit out of sočuvstvie'.

These frames of use suggest that when a person feels sočuvstvie this person recognizes a negative emotional state of another person, experiences a similar state and is willing to show it. This emotional experience can cause the person to want to help the person in trouble. I will now discuss in more detail each semantic component of the word.

The awareness of the bad condition and the consequent bad feeling of another person

Awareness of the bad condition and the consequent bad feeling of another person is a prerequisite for the feeling of sočuvstvie. Sočuvstvie collocates with words describing the state of another person like gore 'grief/woe', nesčast'e 'misfortune', beda 'distress', položenie 'condition', sostojanie 'state', which capture a variety of situations when a big or small misfortune befalls a person and causes this person's negative emotional reaction. The range of these 'misfortunate' events extends from not very serious to more severe ones (e.g. being cheated by a salesperson in a grocery store, having to go far away from home, being criticized in every newspaper, being lonely, being unemployed, being old, etc.). The bad state of another person can be objectively recognized, i.e. it is clear that something bad happened to this person and because of this, this person is in pain. Thus, I will propose the following semantic components to show that the awareness of the bad condition of another person and his/her consequent negative emotional state are a part of the meaning of sočuvstvie:

$\mathrm{X}$ knows that something bad happened to $\mathrm{Y}$

$X$ knows that $Y$ feels something bad because of this Realization of the negative state of another person and sharing of that state

11 Sočuvstvie is a conscious attitude towards another person's bad state which results from thinking about this person. That is why it is impossible to say *Ja ispytyvaju $k$ nemu sočuvstvie, ne znaju počemu (I feel sočuvstvie for him, don't know why). Thus, it is not a momentary involuntary thought that causes this attitude. To show this in the explication the following component can be proposed:

$\mathrm{X}$ thinks about it for some time 
This process of thinking results in the person's 'sharing'the emotional state of another person. The derivational structure of the word so-čuvstv-i-e (it is formed from the noun čuvstvo 'feeling'with the prefix so- expressing a shared activity and a nominal suffix $-i-$-) suggests that this emotional experience implies feeling 'together' with another person, i.e. sharing of his/her emotional state. The prefix so- can be regarded as a productive morpheme of Russian. Sočuvstvie along with sostradanie are among an array of words formed with this prefix: soavtor 'co-author', sožitel' co-habitant', součastnik 'accomplice/ co-participant', sovladelec 'joint owner/'co-owner', sodejstvovat' 'assist/'co-act', sovremennik 'contemporary/co-timer', sotrudnik 'employee/co-worker', soslučivec 'colleague/co-servant', sobesednik 'interlocutor/co-communicator', soobščnik 'accomplice', soratnik 'brother-in-arms', soglašat'sja 'agree/co-say', etc... In all these words so-is felt as a distinct part of the word adding a certain meaning to it. This semantic component is « the same »: soavtor - a person who writes the same book, sožitel'- a person who lives at the same place, sosluzivec - a person who works at the same place, sovladelec- a person who owns the same thing, etc. What is shared in the cases of sočuvstvie and sostradanie is the feeling. This leads us to the following component in the explication:

when $\mathrm{X}$ thinks about it, $\mathrm{X}$ feels the same.

Some collocations from the corpus prove that sočuvstvie is associated with emotional experience of a strong character: serdce razryvaetsja/nadryvaetsja ot sočuvstvija 'the heart breaks/tears apart from sočuvstvie'.

The desire to do something good for another person in order to stop his/her negative emotional state

Sharing of the negative feeling which results from thinking about misfortunes and feelings of another person is only one part of emotional experience associated with soËuvstvie. This emotional state causes the person to do something which can stop the negative emotional state of another person. This desire does not always extend to performing some helpful actions as the following example illustrates:

(1) I ne tol'ko pomošči, no i sočuvstvija bylo ždat'ne ot kogo (Valentin Berežskov).

Not only help, but sympathy [sočuvstvie] was to be awaited from no one. feeling does help another person. The existence of the expression sdelat' čto-to iz sočuvstvija 'to do something out of sočuvstvie'tells about the presence of the component of willingness to do something good for another person in sočuvstvie. Several examples of use of sočuvstvie in the prepositional construction of cause illustrate this point. The existence of the expression dejatel'noe sočuvstvie ('active sočuvstvie'), which means ' sočuvstvie resulting in a helpful action', can also support this argument. Thus, I will formulate this component of meaning in the way that it implies a desire to help the person who is suffering:

I don't want $Y$ to feel like this

because of this, I want to do something good for $Y$

A positive feeling towards another person

The desire to do something good for the suffering person is associated with developing a positive attitude towards this person. It is impossible to hate or be indifferent to a person and feel sočuvstvie at the same time. This allows us to formulate the following component of meaning: when $\mathrm{X}$ thinks like this about $\mathrm{Y}, \mathrm{X}$ feels something good towards $\mathrm{Y}$.

The willingness to show one's attitude to the one in trouble 
uvstvie and its derivatives are very productive in the ways this feeling is communicated back to the one experiencing the negative state. Sočuvstvie can be expressed verbally or non-verbally. It can be shown by facial expression - izobrazit'na lice sočuvstvie 'show sočuvstvie on one's face', 'in one's eyes'- $v$ glazax, 'in one's voice'- $v$ golose. The adverb sočuvstvenno 'sympathetically'characterizes various kinds of actions people can do to reveal this attitude: to say, to ask, to sigh, to look, to smile, to become sad, to shrug one's shoulders, etc. The verb posočuvstvovat' (perfective) can be used as a speech act verb as in the following example:

(2) Predstavljaju, kak vam trudno živetsja, - posočuvstvovala emu Dar’ja (čduard Volodarskij).

(I) imagine how difficult your life is - expressed her sympathy [posočuvstvivat' PAST.3SG] to him Dar'ja.

This linguistic evidence shows that communicating the sharing of another person's negative emotional feeling as well as the consequent positive attitude to this person is an important component of the meaning of sočuvstvie, which makes it possible to propose the following wording for it: $\mathrm{X}$ wants $\mathrm{Y}$ to know this.

This leads us to the following full explication of the word sočuvstvie:

sočuvstvie (X ispytyvaet sočuvstvie $\mathrm{Y}$ )

(a) $X$ knows that something bad happened to $Y$

(b) $X$ knows that $Y$ feels something bad because of this

(c) $\mathrm{X}$ thinks about it for some time

(d) when $X$ thinks about it, $X$ feels the same

(e) at the same time $X$ thinks like this about $Y$ :

(f) I don't want $Y$ to feel like this

(g) because of this, I want to do something good for $Y$

(h) when $X$ thinks like this about $Y, X$ feels something good towards $Y$

(i) $\mathrm{X}$ wants $\mathrm{Y}$ to know this

Components (a) and (b) in the explication show that sočuvstvie comes from the awareness of the bad state of another person and this person's negative emotion. Thinking about it (component c) leads to the person's sharing of the negative state of another person (component d). The component (e) marks that a parallel mental scenario develops in the person's mind according to which the person wants to stop the other person's negative emotional state (component $\mathrm{f}$ ) and to do something good for this person (component $\mathrm{g}$ ). This way of thinking results in a positive attitude towards another person (component $h$ ). The desire to express this attitude to the one in trouble is captured in the component (i).

The meaning of sostradanieThe syntactic frames of use of the word sostradanie

The major frames of use of sostradanie are similar to those of sočuvstvie, which suggests that most of the semantic components are shared by these words. However, among the words expressing emotional experience sostradanie collocates with ispytyvat' 'experience/ feel'only and does not collocate with words of less intensity of feeling (like počuvstvovat' 'feel/have a sensation of' or voznikat' 'arise'). This fact suggests that a stronger emotional experience is associated with sostradanie than with sočuvstvie. There are also no collocations expressing manifestation of the emotional experience associated with sostradanie.

The awareness of the very bad condition and the consequent very bad feeling of another person 
morphological structure of the word so-stradanie suggests that it derives from the word stradanie 'suffering', which means that the character of the state of another person causing this attitude is different from that of sočuvstvie. Sostradanie requires more serious negative conditions of another person to arouse this attitude. The object of this attitude should be suffering and it should be evident to other people. Sostradanie can be felt for orphans, single mothers or old people. Sostradanie is not compatible with words describing certain situations which can cause sočuvstvie. For example, the following combinations will not be possible with the word sostradanie:

(3) *Ja ispytyvaju k nemu sostradanie potomu čto ego obsčitali v magazine.

I feel sostradanie towards him because he was cheated in the store.

(4) *Ja ispytyvaju k nemu sostradanie potomu čto o nem ploxo pičut $v$ gazetax.

I feel sostradanie towards him because bad things are written about him in newspapers.

Thus, the following semantic components can be proposed:

$X$ knows that something very bad happened to $Y$

$\mathrm{X}$ knows that $\mathrm{Y}$ feels something very bad because of this

Sharing of the negative emotional state

The feeling of sostradanie, like sočuvstvie, implies sharing of the emotional state of another person due to thinking about it. Thus, these components in sostradanie will be identical with those of sočuvstvie:

$\mathrm{X}$ thinks about it for some time when $X$ thinks about it, $X$ feels the same

The desire to do something good to another person and a positive attitude towards that person

The following semantic components of sostardanie are similar to those of sočuvstvie as well. Sostradanie is also characterized by a desire to stop the negative experience of another person, to do something good for this person and, consequently, a general positive attitude towards this person. The similarity in combinatorial properties between sočuvstvie and sostradanie, i.e. engagement in propositional constructions of cause, supports this argument. Sostradanie, like sočuvstvie, can imply a helping action. In the following example a woman gets married being driven by sostradanie towards a man with three children who lost his wife:

(5) Sama Karolina Andreevna byla gluboko verujuščej i vyčla zamuž iz-za sostradanija k ovdovevšemu Ambarcumu Egoryču i ego trem osirotevšim detjam... (Lidija Kaleda) Karolina Andreevna was a true believer and got married out of compassion [sostradanie] towards widowed Ambarcum Egoryč and his three orphan children.

Thus, the components (e-h) in sočuvstvie will be a part of the meaning of sostradanie as well.

The final explication of sostradanie will be as following:

sostradanie (X ispytyvaet sostradanie $\mathrm{k}$ Y)

(a) $X$ knows that something very bad happened to $Y$

(b) $X$ knows that $Y$ feels something very bad because of this

(c) $X$ thinks about it for some time

(d) when $X$ thinks about it, $X$ feels the same

(e) at the same time $X$ thinks like this about $Y$ :

(f) I don't want $Y$ to feel like this

(g) because of this, I want to do something good for $Y$

(h) when $\mathrm{X}$ thinks like this about $\mathrm{Y}, \mathrm{X}$ feels something good towards $\mathrm{Y}$

Lidil, 32 | 2005 
explication of sostradanie differs from the one of socuvstvie in two ways. Firstly, the stronger character of the experience of another person and the feeling associated with it are marked by the element very (components a and b). Secondly, the component (i) in sočuvstvie is missing from the explication of sostradanie. There are no examples of communicating this feeling back to the person who is in trouble. In the interpretation of this fact I agree with Levontina, who says that « although sostradanie is stronger than sočuvstvie... in the degree of emotional experience, it is still not possible to compare it to the feeling of the person who is suffering; that is why to attract attention to it might be considered a tactlessness " (Levontina, 2004: 330). Thus, the component of communicating back the experiencing of a similar feeling is not included into the explication of sostradanie.

The NSM method of semantic analysis with the help of universal semantic primitives made it possible to explicate meanings of words describing complex emotions associated with negative experiences of other people. NSM also proved to be a useful tool in capturing semantic differences between words which are close in meaning, but nevertheless present two distinct emotions. Explications framed in NSM can make it easier for learners of a language to understand the meanings of these words and identify semantic links between them.

semantic analysis of the word sočuvstvie has shown that it is a complex feeling, which is caused by the awareness of a negative emotional state of another person associated with some misfortunate event and which results in the sharing of this negative emotional state. When experiencing sočuvstvie, the person develops a positive attitude towards another person who is in trouble due to the desire to stop the negative emotional experience of that person and to do something good for that person. Sočuvstvie is characterized by the desire to reveal this attitude to the suffering person. Sostradanie has the same semantic structure as sočuvstvie, but it is characterized by a stronger character of emotional experience of another person and a consequent stronger negative feeling of the one who feels sostradanie. The component of showing one's attitude and feeling is absent in sostradanie.

Sočuvstvie and sostradanie are important cultural words which support the idea of the significant role of emotional expression in Russian language and culture (Wierzbicka, 1992; 1999; Pavlenko, 2002; Pesmen, 2000). They also extend the value ascribed to communal actions and states to the importance of sharing of negative emotional experiences of others. Thus a detailed semantic analysis was able to show the structures of words which are close in meaning and to link them with significant themes of Russian culture.

\section{BIBLIOGRAPHIE}

APRESJAN, V. (1997): 'Fear' and 'pity' in Russian and English from a lexicographic perspective. International Journal of Lexicography, 10, 2, 85-11.

Lidil, 32 | 2005 
BERDYAEV, N. (2000): Sud'ba Rossii [The Fate of Russia], Moskva/Xar'kov, EKSMO-Press.

BOYM, S. (1994): Common Places: Mythologies of everyday life in Russia, Cambridge/London, Harvard University Press.

COBUILD. BANK OF ENGLISH. <http://www.collinswordbanks.co.uk>

GERHART, G. (2001): The Russian's World: Life and Language, Bloomington, Slavica.

GODDARD, C. (1998): Semantic Analysis: A practical introduction, Oxford, Oxford University Press.

GODDARD, C. and WIERZBICKA, A. (eds). (1994): Semantic and Lexical Universals: Theory and empirical findings, Amsterdam/Philadelphia, John Benjamins.

-, (2002) : Meaning and Universal Grammar: Theory and empirical findings, Vols I, II, Amsterdam, John Benjamins.

LEVontinA, I.B. (2004): Žalost', sočuvstvie, sostradanie, učastie, in J. Apresjan et al., Novyj ob' 'jasnitelnyj slovar'sinonimov russkogo jazyka [New Explanatory Dictionary of Russian Synonyns], 2e izdanie, Moskva - Vena, Jazyki slavjanskoj kul'tury - Wiener Slawistischer Almanach, 327-331.

Nacional'nyj korpus russkogo jazyka <http://www.ruscorpora.ru>

PAVlenKo, A. (2002): Emotions and the body in Russian and English. Pragmatics and Cognition, 10, $1 / 2,207-241$.

PESMEN, D. (2000): Russia and Soul: An exploration, Ithaca, Cornell University Press.

PEYROUX, C. (2004): Gertrude's furor: Reading Anger in an Early Medieval Saint's Life, in J. Corrigan (ed.), Religion and Emotion: Approaches and Interpretations, Oxford, Oxford University Press.

WIERZBICKA, A. (1992): Semantics, Culture, and Cognition: Universal human concepts in culture-specific configurations, Oxford/New York, Oxford University Press.

-, (1999) : Emotions across Languages and Cultures: Diversity and universals, Cambridge, Cambridge University Press.

\section{NOTES}

1. Žalost' (roughly, 'pity') and sopereživanie (roughly, 'empathy') are other Russian language-specific concepts which belong to the same semantic field. Due to the space constraints they are not discussed in this paper.

2. Here and further throughout the work the data were drawn from the National Corpus of the Russian Language, which comprises examples of use of contemporary Russian. 3. So far the most extensive studies of the meanings of sočuvstvie and sostradanie (along with žalost' 'pity' and učastie 'sympathy/interest/ concern') have been done by Apresjan (1997) and Levontina (2004). Both scholars independently of each other provide thorough and thought-provoking comparisons of the four synonyms (žalost', sočuvstvie, sostradanie, učastie). However, in the description of meaning they both rely on culture-specific words (English and Russian respectively) and neither of them arrives at a clear semantic explication of each of the words, which detracts from their semantic analyses and does not help outsiders to clearly understand these words'meanings. 


\section{AUTEUR}

\section{ANNA GLADKOVA}

School of Language Studies, Canberra, Australie. 